\title{
0-181 当科における人工内耳症例（160例）について
}

○藤坂実千郎 ${ }^{1)}$ 、麻生 伸 ${ }^{22} 、$ 中西亮人 ${ }^{1)}$ 、伊東伸祐 ${ }^{1)}$ 、高倉大匡 ${ }^{12} 、$ 將積日出夫 ${ }^{1)}$

富山大学 医学部 耳鼻咽侯科1、みみはなのど あそうクリニック ${ }^{21}$

1994年日本で人工内耳が保険収載され、当科も1996年から富山県初の人工内耳手術を開始した。2001年からは小児手術も 開始し、現在では小児例が全体の約半数を占めているのは全国的な傾向と同様である。手術開始当初はコクレアだけであっ たが、バイオニクス、MED-ELが保険適用となり、手術手技はコクレオストミーから正円空窩アプローチが主体となって きた。また2014年には残存する低音聴力を活用する EAS が保険収載され、低侵襲の手術手技が重要となっている。

当初は中耳炎症例が基本的に禁忌であったが、OMAAV や好酸球性中耳炎など症例はまれであるが、手術困難症例も対象 となった。人工内耳ガイドラインも、小児例は 2 歳から 1 歳と低年齢化し、成人例も 2017 年に聴力レベルが $90 \mathrm{~dB}$ 以上から $70 \mathrm{~dB}$ 以上と大きく変更され、今後対象患者も増加することが予測される。

今回われわれは当科が 22 年前から開始した人工内耳手術症例 160 例について振り返り、対象症例の原因疾患、聴取成績や 合併症などについてまとめ、これを報告する。

\section{0-182 残存聴力活用型人工内耳術後聴力の長期成績}

東野哲也、下荒翔研、奥田 匠、中島崇博、我那覇 章

宮崎大学 医学部 耳鼻咽㘈・頭頸部外科

蝸牛への低侵襲な電極の改良と手術方法の進歩により、少なくとも短期的には低音域の残存聴力を高率に温存が可能とな った。低音域は音響刺激、中・高音域は人工内耳の電気刺激で音情報を伝達する人工聴覚器が開発され、高音急墜、障害型 感音難聴者を主な対象とした「残存聴力活用型人工内耳」として2014年から保険診療が行われている。当科で2009年から 2014年に行われた残存聴力活用型人工内耳症例は10例について、術後 $4 \sim 9$ 年間の聴力経過を報告する。全例とも両側高音 障害型感音難聴例の一側に残存聴力活用型人工内耳を活用しており、手術時年齢は平均51歳（21７5歳）であった。全例と も術後 2 年間の低音域聴力閾值は保たれたが、10例中 3 例は術後 2 年後より緩徐な悪化を示した。メニエール病の 1 例は 2 年後に急性の残存聴力喪失を来したが、電気刺激のみで語音聴取成績は維持できている。遅発性の原因を特定することは難 しいが、術後の長期経過を考虑した上で適切な電極選択が必要と考えられる。

\section{0-183 Underwater 法による人工内耳埋め込み術の灌流液について}

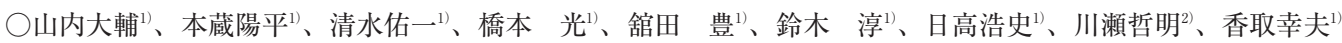
東北大学 医学部 耳鼻咽喉科・頭頸部外科 ${ }^{11}$ 、東北大学 医工学研究科 聴覚再建医工学分野 ${ }^{2}$

われわれは2014年より Underwater 法による人工内耳埋込手術を施行している。上鼓室へ細径のチューブを留置し、シリ ンジポンプを用いて 70 100 $\mathrm{ml} /$ 分で灌流液を流入し、鼓室を浸水下に行う手技である。本術式によって内耳開空時に空気 の混入を防止し、また外リンパ組成に近い灌流液を用いることで、物理的、生理的な蝸牛障害を軽隇することが可能とな る。灌流液として2016年ころまでは生理食塩水を用いていたが、その後は人工䯣液（アートセレブ、大塚）に変更してい る。人工髄液は glucose や、HCO3-、Ca2+、Mg2+などの電解質も含んで抒り、脳外科領域に扔いて脳神経組織の保護 に優位であることが実証されており、内耳に抒いても生理的環境を維持し、より保護的な手術が可能となると考えている。 Underwater 法を供覧しつつ、当科に扔ける人工内耳症例の術後インピーダンスについて解析したので報告する。

\section{0-184 次世代シークエンス解析で MYO15A 変異が認められた成人重度難聴症例に対し 人工内耳埋め込み術を施行した 1 例

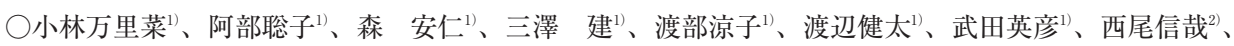 宇佐美真一 ${ }^{2}$ \\ 国家共済組合連合会 虎の門病院 耳鼻咽喉科 ${ }^{12}$ 、信州大学 医学部 耳鼻咽喉科 ${ }^{2}$}

2012年に先天性難聴の遺伝学的検查が保険適応となり、難聴医療での活用例が増えている。また信州大学耳鼻咽喉科との 共同研究により保険収載されている以外の難聴の原因遺伝子が特定できるようになり診断率も向上している。先天性難聴の 半数以上は遺伝子が原因であるといわれており、報告例を重ねるにつれ、同じ遺伝子でもさまざまな表現型を呈することが 明らかになっている。今回 3 歳時に両側感音難聴の診断となり、徐々に聴力が悪化。24歳時に身障 6 級を取得し、補聴器装 用を開始。65歳時に身障 2 級取得し、67歳時に人工内耳埋め込み術を施行した症例を経験した。遺伝学的検査の結果、MYO $15 A$ 遺伝子複合へテロ接合体変異が見出され原因が明らかになった。MYO15A 遺伝子変異による難聴症例に人工内耳埋め 込み術を施行した報告例は少なく、長期の難聴期間を経て高齢になってから人工内耳埋め込み術を施行した $M Y O 15 A$ 難聴 症例の報告は本症例が初めてである。本症例での術後経過と成績について MYO15A 難聴の臨床像と共に報告する。 


\section{0-185＼cjkstart神経線維腫症 II 型患者に人工内耳挿入後、MRI により人工内耳磁石逸脱を来した 1 例}

○高浩史 ${ }^{1)}$ 、須納瀬知輝 ${ }^{2)}$ 、本蔵陽平 ${ }^{22}$ 、山内大輔 ${ }^{2}$ 、香取幸夫 ${ }^{22}$

関西医科大学 耳鼻咽喉科頭頸部外科 ${ }^{12}$ 、東北大学 医学部 耳鼻咽喉・頭頸部外科 ${ }^{22}$

人工内耳術後の場合でも、適切な前処置後に $1.5 T$ 以下の MRI 検査は可能とされている。今回、両側聴神経腫瘍と脊䯣腫 瘍を伴う神経線維腫 II 型の患者で、1.5T の MRI により人工内耳体内磁石の逸脱が生じた例を経験した。

症例は31歳男性。左人工内耳挿入術（Cochlear, CI512）を施行し、経過は良好であった。 5 力月後に他院で脊䯣腫瘍の術 前 MRI（1.5T）検查を受けた際、包帯を装着するも疼痛と検查直後より挿入部の腫脹が出現した。当科のX線撮影で磁石 上方が逸脱しており、用手的整復は困難で外切開による磁石整復を行った。この際、磁石と反応しない非磁性体器具が有用 であった。

術後 9 カ月めに当院での MRI 施行を依頼され、スプリントとヘッドバンドでインプラント埋込部を固定して $1.5 T$ T MRI に臨んだが、施行前に疼痛のために検查を中止した。直後にX線撮影で体内磁石のずれを確認し、透視下に用手的に整復し た。そこで後日、0.3Tの MRI 撮影を行った。その後も聴取能は問題なく経過し、現在も装用中である。

\section{0-186 急性高度難聴による失聴を伴って発症した Good 症候群に対して人工内耳埋込術を施行した 1 例}

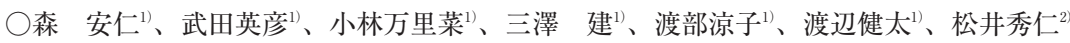

国家公務員共済組合連合会＼cjkstart虎の門病院 耳鼻咽喉科 ${ }^{12}$ 、東邦大学医療センター大森病院 耳鼻咽喉科 ${ }^{2}$

症例は45歳女性、44歳時に慢性的な咳嗽や発熱を繰り返し、近医を受診した。精查中に急速に進行する感音難聴を来し、 ステロイドパルス療法を施行したが効果にそしく、約 1 カ月の経過で両側失聴に至った。難聴と同時に急性肝不全を発症 し、サイトメガロウイルス感染症の診断となり、免疫グロブリン大量静注療法掠よび抗ウイルス薬にて治療を行った。精査 の結果、胸腺腫と低 $\gamma$ グロブリン血症を伴う後天性免疫不全症候群（Good 症候群）の診断に至り、全身状態が改善した後 に免疫グロブリン補充療法を開始された。胸腺腫摘出術を施行した後に、両側高度感音難聴に対して右人工内耳埋込術を施 行した。周術期や術後に感染症などの合併症を来すことなく経過良好であった。術後半年で良好な補聴効果を得ることがで きた。Good 症候群は本邦では約40例、世界で約150例の報告があるが、両側失聴に至った症例は非常にまれである。人工 内耳埋达術を施行した例はわれわれが渉猟し得た限り本例が初めてであり、文献的考察を加えて報告する。

\section{0-187人工内耳手術を施行した Charcot-Marie-Tooth 病の 2 症例}

○吉田忠雄、小林万純、下野真理子、杉本賢文、寺西正明、曾根三千彦

名古屋大学 医学部 耳鼻咽喉科

Charcot-Marie-Tooth (CMT) 遺伝性ニューロパチーは、慢性の運動・感覚多発ニューロパチーを特徴とする疾患群であ る。今回、難聴を主訴に当科受診し、人工内耳治療後にCMT 病と診断された症例について報告する。CMT病は、常染色 体優性、劣性、X連鎖性遺伝形式をとり、少なくとも40の遺伝子および遺伝子座が関連する。また、CMT 病は症候群性の auditory neuropathy (AN) の原因の一つである。聴神経の脱髄や軸索障害により神経伝導の同期障害が生じるため AN の症 状を呈すると考えられる。聴神経そのものの障害と考えられるため、人工内耳治療は困難であると通常考えられるが今回の 2 症例では通常の人工内耳術後の経過よりは緩やかであるものの実用的に十分な聴力を得ることが可能であった。過去に CMT 病の難聴に対し、人工内耳を行った報告は 3 例存在するが、いずれも今回の報告と同様の経過を示している。過去に AN、螖牛神経低形成、聴神経腫瘍等でも人工内耳の有用性が報告されているが、CMT 病に伴う難聴においても人工内耳が 有効であることが示された。

\section{0-188 経外耳道的内視鏡下耳科手術を円滑に進めるために}

○西池季隆、上塚 学、道場隆博、小幡 翔、大谷志織、梅田直睴、佐々暢亜、河辺隆誠

大阪労災病院 耳鼻咽喉科・頭頸部外科

経外耳道的内視鏡下耳科手術（transcanal endoscopic ear surgery：TEES）は低侵襲である以外にも、死角の減少や病変 の拡大視による詳細な観察等、利点は多い。しかし内視鏡下手術にまつわる課題として、内視鏡スコープの取り扱い、片手 操作や出血への対応等の問題点がある。これらが足かせとなって TEES の導入をためらう施設もあると推測する。また鼓膜 や鼓室の病変に対するTEES の外耳道を経由するアプローチは理にかなっているが、病変が乳突洞に存在する際の TEES の 適応やその対応には議論があるところである。今回これらの問題点に対して、当科で行っている工夫や対策に関して報告す る。内視鏡の持ち方や位置によって手術画像がどのように変化するか、若手医師と指導医による手術画像を比較提示する。 また術中の出血に対する当科の工夫に関して解説する。乳突洞病変に対する対応を供覧する。 